\title{
Report of the Standing Committee on Labour, Employment and Immigration
}

The following is a condensed version of the report of the Standing Committee on Labour, Employment and Immigration, presented November 7, 1985 to the House of Commons. The report was divided into the Plaut Report recommendations and the Committee response. This condensed version merges the two sections to avoid redundancy, and leaves out material which simply repeats the Plaut Report's recommendations or which is dealt with elsewhere in this issue.

$$
\star * *
$$

The combination of the Plaut Report and the oral and written testimony of witnesses has enabled the Committee to consider each of the options suggested by Rabbi Plaut...Where the Committee does not agree with Rabbi Plaut, the Committee has made recommendations in the belief that if the Parliament of Canada were to follow its advice, the result would be the system most likely to work in both an efficient and very human way.

...The decision to provide the protection of Canada to those who have wellfounded fears of returning to their own country should be undertaken by a body of people knowledgeable and sensitive to human rights issues rather than immigration issues. The determination decision is not an immigration matter but instead a decision as to who are Convention refugees in need of Canada's protection. Care must be taken to make sure that...refugee claimants are dealt with by a refugee determination system that is not part of our immigration system.

It is the Committee's belief that the immigration decision, which follows a determination of refugee status, should remain in the hands of the Minister responsible for immigration.

Four basic principles are fundamental to the approach of the Committee and the recommendations it has made:

1. It is the Committee's strongly-held conviction that Canadians do not want people sent back to countries where they may be persecuted.

2. Every person in Canada who wishes to claim that he or she is a Convention refugee should have an unqualified right of access to a formal process that will adjuducate the claim.

3. All Convention refugee claimants should have their case decided at a nonadversarial oral hearing.

4. The decison-maker in the formal process shall have the power, in addition to declaring an individual to be a Convention refugee, to recommend to the Minister that specific individuals who are not within the strict definition of Convention refugee nevertheless should be considered for landing on compassionate and humanitarian grounds.

\section{Access Criteria}

\section{Definition of Convention Refugee}

\section{a) Exclusion and Cessation Clauses}

Rabbi Plaut believes that although Canada has incorporated the general definition of a Convention refugee and the principle of non-refoulement into the Immigration Act (section 2(1) and section 55 respectively)...[he] recommends that the...exclusion and cessation clauses of the UN Convention be incorporated into Canada's statutory definition of a refugee (i.e., exclusion of refugees receiving UN assistance and "natural" refugees, cessation of refugee status upon reavailment of national protection or acquisition of lost or new nationality, etc.).

The Committee disagrees with this recommendation... These exclusion and cessation clauses provide little or no benefit to the refugee determination process and... few of the exclusion clauses apply directly to the refugee situtation in Canada. Inclusion of these clauses may therefore cause confusion and difficulty for those whose responsibility it is to determine refugee status.

\section{b) Prior Protection}

...Individuals may not be entitled to remain in Canada if they have received protection in another country which is a signatory to the Convention prior to coming to Canada... As a test to determine whether prior protection actually exists, Rabbi Plaut proposes that a Convention refugee should not be removed from Canada unless he or she is:

$$
\text { - "a person who is a permanent re- }
$$

sident of another state and has an absolute legal right of re-entry into that state not subject to the exercise of discretion by border officials. Such residency must be permanent and not for a stated term of months or years;

- or is a person who has a valid Convention travel document with a return clause." (p. 67)

The Committee recognizes that refugees must not be bounced from country to country (i.e., refugees "in orbit"). Nevertheless...the status of permanent residence has no relevance in many countries of the world because they only distinguish between foreigners resident in their country for a limited period of time and citizens. Residency permits are valid for a stated period of time and must be renewed. Consequently, prior protection in Western Europe, for example, would not be recognized in Canada under Rabbi Plaut's test.

The alternative criterion, possession of a valid Convention travel document with a return clause, could accentuate the already-prevalent practice of destruction of documents.

The UNHCR has stated that refugees may be returned to a country which has previously protected them against refoulement and will allow them to remain under minimum recognized standards until a durable solution is found. Provided these conditions are met and due consideration has been given to Canada's policy of family reunification, the Committee believes that Canada should be allowed to return Convention refugees to countries which have previously protected them.

\section{Right to Make a Claim}

The Committee agrees with Rabbi Plaut that access to the refugee determination process is a right, not a privilege. It further supports his recommendation that there be no distinction between "in-status" and "out-of-status" claims, in other words, between refugee claimants who have entered Canada legally and those who have entered illegally.

Continued... 
Continued from page 3

\section{Inadmissible Claim}

\section{a) Definition}

...(Although) Rabbi Plaut feels that the concept of manifestly unfounded claims (bogus claims) is practically unworkable, open to administrative misapplication and should be abandoned, he... recommends that claims which fall within one of ... three categories [legally inadmissible, expired time limits, and repeat claims with no new evidence] be dealt with in a special way.

To ensure that all individuals in Canada have equal access to the process of refugee determination, the Committee believes that the concept of an inadmissible claim should not be adopted. The Committee also believes that if the original claim is negatively determined, then claimants should be provided with a mechanism that would allow them to present evidence dealing with a change in circumstances.

\section{Structure}

\section{Refugee Officer}

Rabbi Plaut recommends maintaining a link between the Canada Employment and Immigration Commission (CEIC) ... (and) the refugee determination process (through)... a new category of CEIC personnel called a Refugee Officer (RO). ROs will act as liaison between CEIC and the Refugee Board (RB); interview refugee claimants within 24 hours of their arrival in Canada; guide refugee claimants to proper resources, especially counsel and support systems; identify inadmissible claims; identify cases which qualify for consideration under special programs; and identify those cases requiring enforcement action (p. 72, 73, 81 and 104). ROs should be selected by a joint committee of the RB and CEIC and be seconded to the RB on a contract basis for three-year terms at least (p. 72-73).

The Committee agrees that a new position called a Refugee Officer should be created. However, the Committee also believes that Refugee Officers should be selected and employed by the Refugee Board and not the CEIC. The duties of this position should be restricted to those of a facilitator rather than a decision maker. For example, assisting refugee claimants in securing the necessary resources to make a claim, providing information on special programs and indicating when claimants are ready for their hearing would all be appropriate activities. ROs could also be present at the Board hearing to ensure that refugee claimants' cases are fully presented.

From time to time, members of the Refugee Board should function as Refugee Officers in order to become more sensitive to the needs of refugee claimants.

The Committee believes strongly that Refugee Officers should not have any enforcement responsibilities. Ideally they would be selected from the local immigrant aid community and, in most cases, would be part-time employees of the Refugee Board... Refugee Officers should be specifically trained in matters pertaining to refugees.

\section{Refugee Board}

\section{a) Creation of the Refugee Board}

The Committee agrees with (Plaut's) recommendation to create a new body to determine Convention refugee claims. However, the name of this new body should be the Convention Refugee Determination Board (CRDB). The Committee agrees that this body should have three divisions: Hearings, Documentation and Information, and Education. The Committee further recommends that the CRDB should be located in Toronto, in view of the large number of claims made there. The CRDB should be headed by a refugee commissioner.

The Committee is strongly opposed to integrating the CRDB and the Immigration Appeal Board ...the CRDB (should) be a board directly supervised in its administrative capacities by the Minister's office... This structure offers the greatest scope for approaching refugee determination in a non-adversarial setting. With regard to hearing rooms, there will be a need for permanent facilities in Toronto and Montreal, while in other communities existing community facilities could be used on a part-time basis.

The Committee recommends that the federal government consult with the provinces before establishing the CRDB and implementing the model proposed by the Committee. In addition, the government should consider providing the provinces with an ongoing advisory role in matters pertaining to refugee claimants.

\section{b) Powers and Duties of Members}

As Plaut recommends, in making a determination, members of the RD should not be bound by the strict rules of 'evidence (p. 124). Hearings should be non-adversarial. The RB should have the exclusive jurisdiction to limit cross-examination and the power to subpoena witnesses and administer oaths (p. 124-125). RB members should be permitted to ask questions of the claimant for clarification. The RB should be allowed to refer a case deserving of humanitarian consideration to the Minister with a favourable recommendation (p. 85 and 129).

The Committee believes that...in matters pertaining to detention, the Board could offer advice to the counsel of detained claimants ([but not] present its views to an adjudicator for release of a claimant who is in detention [p.81]), but it should remain the responsibility of claimants or their counsel to argue their own case at detention hearings.

\section{c) Appointments}

The Plaut Report proposes that there should be a full-time member on each panel hearing a case. These members should be appointed by the federal government for a period of five to seven years. Where panels consist of more than one member, additional members should be selected from the public on a part-time basis. All members should be appointed on the basis of their expertise in the area of refugees, their knowledge of refugee law and their human sensitivity. Before appointments are made, non-governmental associations would be invited to suggest names for appointments to the panels, both as professional and as public members (p. 132-134).

The Committee agrees with the thrust of these recommendations. Expertise should be the guiding principle and consequently the Committee believes that the requirement to have one full-time member on each panel is too restrictive.

\section{d) Training}

The Committee agrees with the Plaut Report recommendations that the Education Division of the RB be responsible for providing initial and on-going training of all who are involved in the refugee process, conduct seminars and conferences in various parts of Canada and act as a general information office on behalf of the RB. In addition, it would disseminate information collected by the Documents and Information Division to panel members throughout the country (p. 142). 


\section{e) Rules of the Refugee Board}

... The Convention Refugee Determination Board should be allowed to establish its own rules... (to) reflect the nonadversarial nature of the proceedings.

\section{f) Guidelines}

Rabbi Plaut recommends continued use of the Minister's guidelines (IE 8.06-8.09) (for RB procedures), since these reflect internationally accepted standards. In addition, the UNHCR Handbook on Procedures and Criteria for Determining Refugee Status should be incorporated into the RB's guidelines (p. 126).

The Committee... feels that because of the complexity of the UNHCR Handbook there is no need to incorporate it into the guidelines. The Minister should review the UNHCR Handbook to ensure that Canadian procedures reflect its spirit.

\section{The Models}

Testimony indicated that a new refugee determination process should be fair and provide equal access to all. It should also be as efficient and speedy as the requirements of fundamental justice permit... The Committee has decided to propose its own model (in which) ... all refugee claims will be heard orally, in a nonadversarial setting, by panels composed of two members located in the region where the claim is made... If one member of the panel makes a positive determination, then the claimant is deemed to be a Convention refugee. In the event that both members of the panel make a negative determination, they must then decide whether a recommendation should be made to the Minister to issue a permit to the claimant on humanitarian and compassionate grounds.

If a claimant receives a negative determination and is not permitted to remain in Canada on humanitarian or compassionate grounds, then the claimant may appeal the decision to the Federal Court of Appeal, with leave of that Court...The grounds of appeal should be broad. The Committee is not proposing that the Minister be given the same right of appeal. The Committee believes that the availability to the Minister of a review under section 28 of the Federal Court Act for errors of law and jurisdiction will be sufficient.

There should be some procedure for the refugee claimant to present for reconsid-
"Every person in Canada who wishes to claim that he or she is a Convention refugee should have an unqualified right of access to a formal process that will adjudicate the claim."

\section{Report of the Standing Com- mittee on Labour, Employment and Immigration}

eration information... on a change of circumstances pertaining to conditions in the countries from which refugee claimants flee... In view of the gravity of this decision the Committee urges that procedural protections for claimants be devised and recommends that the Convention Refugee Determination Board be responsible for the reconsideration decision. At the same time the potential for abuse should be minimized.

\section{Rights of Convention Refugees in Canada}

\section{Application for Permanent Residence}

The Committee agrees that the process of landing applicants individually, by Order in Council, is too lengthy, and may impede the settlement of the refugee... The Immigration Act might be amended directly, as Rabbi Plaut recommends, or it may be that sufficient authority already exists under section $9(1)$ of the Act to achieve the same thing through a regulation exempting Convention refugees from the requirements to obtain a visa before entering Canada. This change should also apply to individuals accepted for humanitarian and compassionate reasons.

The Committee agrees that the current practice of issuing Convention Travel Documents to refugees to facilitate their travel abroad should continue.

\section{Family Reunification}

The Committee strongly supports the speedy reunification of refugees with their families... (but) finds it unnecessary, however, that they be automatically recognized as refugees. The Committee agrees with Rabbi Plaut's recommendation that Minister's permits should be issued to the family as a matter of course and that the Immigration Manual should reflect this policy.

\section{Protection Against Removal}

Under Section 55 of the Immigration Act refugees may be returned to the country in which they fear persecution... in certain circumstances (i.e., if convicted of a serious offence, for espionage, threat of subversion, etc.)... Rabbi Plaut suggests that this section of the Act should be amended. The Committee is not persuaded that any changes to Section 55 are warranted where serious offences are concerned. It appears that Rabbi Plaut intended the test of "serious threat to the public safety" to be a higher test, therefore more beneficial to refugees, than the test of an offence for which the maximum sentence is 10 years imprisonment or more (according to Canadian equivalences). The Committee is not convinced that Rabbi Plaut's test is more beneficial to refugees and prefers the certainty of the more clearly-defined standard...Consideration of serious crimes should remain under the jurisdiction of the Minister.

The Committee agrees that refugees should have a right to respond to the serious allegations made against them under Section 55 of the Immigration Act before removal to a country where they fear persecution... They are not, however, given an opportunity to reply to the allegations, either orally or in written form. Because the certificate which is issued on the basis of those facts (after investigation by the Review Committee) is "conclusive proof of the matters stated therein" (s. 40(2)), the refugee has no opportunity to respond to its contents in order to contest his removal.

The Committee feels that this is a denial of natural justice and urges that refugee claimants be given a right of reply before deportation to a country in which they have a well-founded fear of persecution.

\section{Right of Review and Appeal}

Rabbi Plaut recommends that if a Convention refugee's application for permanent residence is refused, he or she should have the right of appeal to the Immigration Appeal Board (IAB) on legal and equitable grounds. If the refusal involves the issue of national security and evidence cannot be disclosed, then a security certificate would be filed and the IAB would 


\section{Continued from page 5}

be limited to reviewing only the legality of the refusal (p. 90).

In the Committee's model there is an appeal with leave of the Court. The Committee recommends the application for appeal should be made within 15 days of reciept of the decision of the CRDB ... and agrees that if the Federal Court allows the appeal then it should have the power to reverse the decision of the CRDB or order a rehearing.

At present, a refugee claimant who has received a negative determination and is subject to a removal order is entitled to a judicial review of the decision. There is no right of appeal. The Committee does not recommend that this be changed but agrees that all actions before the Federal Court should be considered together.

\section{Commission Counsel}

The Committee strongly endorses the non-adversarial approach to refugee determination ... It may be that in many cases it will not even be necessary for CEIC counsel to be present at the oral hearing before the Board. When CEIC counsel do present relevant evidence, this must be communicated to the claimant prior to the oral hearing.

\section{Inquiries}

\section{Decision to Hold an Inquiry}

The Committee has earlier rejected any enforcement role for the Refugee Officer and consequently disagrees with Rabbi Plaut's recommendation that the $\mathrm{RO}$ should determine if the claimant should be the subject of an inquiry. The Committee further agrees with the numerous witnesses who noted that the basic data form contains more information than is necessary at that stage.

\section{Offences and Punishment}

Although present policy of the government is not to prosecute refugees for immigration offences pending determination of their claims (for false documents, illegal entry and so on), the Immigration Act is silent on the point. The Committee agrees (with Plaut) that such an important matter should not rest on a policy decision but should be part of the Act itself... (and that sections 58 and 59 of) the Criminal Code... dealing with pass- port and certificate of citizenship offences... (should) be amended as well.

\section{Adjudication Decision Review}

Rabbi Plaut suggests that there may be a need to review decisions by adjudicators regarding the detention of refugees... Decisions of adjudicators concerning refugee claimants should be discussed periodically by adjudicators, CEIC, ROs and members of the RB (p. 82).

The problems of the detention of refugees and the role of adjudicators must be seen as part of the larger problem with immigration detention generally which the Committee identified in its Fourth Report to Parliament ... The Committee urges that further actions be taken on recommendations one and six in that Report.

\section{Classified Information}

\section{Documentation Division}

The Committee does not envisage the need for the Documentation Division to collect classified information on claimants. However, the Committee agrees with (Rabbi Plaut's) recommendation, as it pertains to country-specific classified information, that classified information be segregated and accessible to members of the $\mathrm{RB}$, the director of the Documentation Division and the staff of the Division (including legal research counsel) (p. 141).

\section{In Hearings}

Since refugee determination hearings will not deal with the issue of exclusion, then the relevance of classified information dealing personally with claimants is diminished. However, in the event that classified country-specific information is used in a hearing, the Committee believes that the source of this information should not be revealed and claimants should be given the opportunity to respond to this information.

\section{Support}

\section{Employment Authorizations}

Since Rabbi Plaut recommends that all persons have a right to make a refugee claim in Canada (regardless of their immigration status), then they should also have the right to apply for employment authorizations. The sole criterion for receiving an employment authorization should be financial need. Rabbi Plaut supports the use of generic work permits and claimants should be permitted to use Canada Employment Centres (CECs). Claimants should be informed immediately that a medical examination is required before a generic work permit can be issued (p. 145-148). The Committee agrees with these recommendations.

\section{Social Assistance}

According to the Plaut Report, "The task of making sure that claimants are provided with the necessities of life is an obligation of the provinces as it is of the federal government and claimants should be assured proper treatment."

The Committee agrees that these services should be provided and this should be achieved through a federal-provincial agreement.

\section{Student Authorizations}

The Act should be amended without delay to permit student authorizations to be issued to refugee claimants and their families in Canada.

\section{Claimant Identification}

Rabbi Plaut recommends that refugee claimants should receive special documentation that would serve to identify claimants as people who qualify for certain privileges. He feels that the document contained in Appendix VI is suitable, providing the title is changed and the box referring to money is removed (p. 150-151). The Committee agrees with this recommendation.

\section{Right to Counsel}

Rabbi Plaut recommends that the Education Division, with the assistance of the UNHCR, should prepare and display, at major ports of entry, a pamphlet which outlines the rights of refugees, Canada's legal processes and practices in relation to refugee claims and a list of local agencies which may provide assistance to refugees (p. 126). He also suggests that it would be "helpful if in the major refugee centres NGOs would pool their resources to establish an information office where the claimant may receive additional advice and assistance and be provided with names of lawyers who practice in the refugee field." (p. 158) The Committee agrees with this recommendation.

At present the right to counsel is guaranteed to any person who is the subject of an inquiry (Immigration Act, section 30). 
The Committee feels that it is not necessary or practical to provide individuals with a right to counsel prior to an inquiry. However, in the event that any information taken prior to an inquiry is used against a refugee claimant, then the claimant must be made aware of this information prior to the hearing and be given the opportunity to respond to it.

In order to ensure the availability of counsel at detention review, the Committee recommends that the Immigration Act should be changed to allow refugee claimants the option to postpone the initial review following the decision to detain for up to 120 hours from the present 48 hours.

According to Rabbi Plaut, "At a minimum, discussions should be held with provincial legal aid plan administrators to ensure claimants are not denied (legal aid) certificates." (p. 159)

\section{UNHCR Participation}

UNHCR participation in an advisory capacity has proven to be beneficial in the Canadian context and this should be continued (p. 163).

The Committee disagrees with (Plaut's) recommendation (that a transcript of a rejection be submitted to the UNHCR for review) since UNHCR participation of this type is not required in the model proposed by the Committee because a decision to reject a claimant must be unanimous. The Committee agrees with the three remaining recommendations (to postpone panels pending UNHCR advice, to allow the UNHCR to attend hearings as amici curiae, and to sit as an ex-officio member of the Documentation Division) with the reservation that any opinions of the UNHCR representatives must be expressed in the presence of the refugee claimant.

\section{Interpretation}

Although the Committee agrees that interpretation services in refugee hearings need to be improved, it does not feel that it is in a position to make the necessary administrative recommendations to accomplish this. The Committee urges the government to examine the feasibility of each of Rabbi Plaut's suggestions. The Committee also believes that care should be taken to ensure that interpreters are not biased against the best interests of the claimants.

\title{
Dissenting Statement on the Fifth Report of the Standing Committee on Labour, Employment and Immigration
}

\author{
Dan Heap, M.P., Spadina \\ (edited version)
}

Although much of this report is good, I find two serious flaws in it. The pressure of Committee work on all members was such that we could not find time to resolve these points. Because of these two flaws I dissent from the report, as follows:

\section{The Appeal System}

The Committee disposes in one paragraph of the refugee claimant's right to appeal. It recommends an appeal, with leave, "on broad grounds," to the Federal Court of Appeal. This will not work.

All the witnesses before the Committee asked for a stronger appeal system. Remeber the Supreme Court's warning, in its April 4 decision on the Singh case, that a mistaken judgement may cost a person's liberty or life.

\section{Therefore I recommend that we set up a special appeals branch of the Convention Refugee Determina- tion Board. A claimant who asks to appeal would have the written record of his case read by one mem- ber of the branch who would decide whether the claim is "manifestly unfounded" and if so deny leave to appeal. If leave were not so denied, the case would be heard by an ap- peals panel with a mandate to hear and examine the claimant afresh, hear and examine other witnesses, and invite the opinions and advice of the UNHCR representative.}

\section{Right to Counsel}

Many witnesses told us how genuine refugees' cases have been prejudiced because they were denied the right to have a lawyer or other counsel at the first examination.

A refugee arrives, scared from previous persecution, often not knowing our languages and laws, and is quizzed alone by a uniformed Enforcement Officer trained to discover reasons to keep people out. This contradicts the whole thrust of our report, which is to separate determination of refugee status from immigration procedures.

Furthermore many witnesses told the Committee, and the Sub-Committee on Immigration Detention, how some refugees, without right of counsel, have been unjustly detained and sometimes unjustly treated in detention.

The Supreme Court, in deciding that refugee claimants must have an oral hearing, implied that everyone physically in Canada has certain rights under the Charter. I believe, with most witnesses before the Committee, that right of counsel is one of these, and that evidence taken without counsel ought to be excluded from decision-making. To wait years more for the Supreme Court to verify this is surely an unreasonable waste of human suffering and taxpayers'money.

Therefore I recommend, with Rabbi Plaut, "that the refugee claimant have the right to counsel as soon as a claim is made, that he/she be advised of this right and that it be enshrined in our legislation." (p. 158, Refugee Determination in Canada).

I strongly regret that the many beneficial recommendations of the Committee's Report may be of no help to a refugee if we deny him/her the right to a strong appeal and the right to counsel from the beginning.

Therefore I oppose this report as a whole, and urge the public to persuade the Minister to correct these flaws. 